\title{
THE APPLICATION OF INSTRUCTIONAL MEDIA IN TEACHING ENGLISH TO YOUNG LEARNERS
}

\author{
Tiya Winola ${ }^{1}$ \\ ${ }^{1}$ IKIP Siliwangi \\ ${ }^{1}$ Tiyawinola@student.ikipsiliwangi.ac.id
}

\begin{abstract}
In Indonesia, English is a foreign language, hence not easy to teach English to young learner in Indonesia, thus, need something interesting to teach English to young learners, one of which uses instructional media. Instructional media as a tool needed to facilitate the teachers in presenting the material, but many English teachers in Indonesia find it difficult to use instructional media in the classroom. This study aims to (1) how the teacher applied the instructional media in the classroom. (2) to investigate problems faced by the teacher, and (3) elaborate the teacher's strategies in solving problems using the instructional media. This study was conducted a case study design, by using observation and interviews to collect data. In the investigation teachers do not have free access to use the media provided at school. Thus, they faced obstacles to provide proper media in classroom. Therefore this paper described certain strategies to solve teacher problems in using instructional media in the class.
\end{abstract}

Keywords: Teaching English, Instructional media, Young learners

\section{INTRODUCTION}

English in Indonesia is a foreign language. Therefore, learning English needs to be taught from an early age. Many countries also present English to children in pre-primary settings (Cahyati, Parmawati, \& Atmawidjaja, 2019). Such as in kindergarten and preschool. Young learner is a term for children under 12 years. Babiarz \& Kraj (2019) explain Young Learners such learners as children from the first year of formal schooling (five or six years old) to eleven or twelve years of age. With the unique characteristics of young learners, it is not easy for a teacher to teach English to them What distinguishes young learners from adult learners is Limited attention, they are very quickly bored and lose focus after about 10 minutes (Babiarz \& Kraj, 2019). Need something to make English lessons more easily mastered by students, some aspects that can affect teaching and learning activities in the classroom to be effective and efficient; one of them is instructional media.

The instructional media can help teachers in teaching activities. The media can contribute to the formation of abstract concepts, that the use of appropriate media, improve the quality of learning and teaching English. Muvango, Indoshi, \& Okwara (2019), states instructional media become one of the factors that influence the success of teachers to deliver material and make it easier for students to master the material taught. Instructional media are represented as a means used in educational settings to explain material or information so that the teaching and learning process is effective. Appropriate instructional media is very useful for learning activities in the classroom, especially in teaching English Some advantages in using instructional media. 
Trough the use of media, subject content can be selected and managed more precisely, improving the quality of teaching by the teacher, subject content can be delivered in an organized, consistent, specific, and clear manner. According to Soliu \& Elisha (2018) Educational media are a broad-range of resources which can be used to facilitate effective and efficient communication in the teaching and learning process. But when teaching English to young learners, teachers rarely use the media to attract attention and motivate them. However, for the time being the data in the field shows that teachers tend to use conventional methods that emphasize the use of books. As a result, students are less interested in learning so that they interfere with the absorption of material in class which causes students to not only get bored but also not understand the material (Apsari, Lisdawati, \& Mulyani, 2020).

Various types of media that can be utilized to teach English. According to Soliu \& Elisha (2018) divided instructional media into three types, namely audio, visual, and audio - visual aids, (1) Audio Aids - is a instructionals media that students can hear but cannot see, e.g. radio, a tape recorder program where students can only hear and listen to programs. (2) Visual aids - are instructionals media that can be seen, but there is no sound accompanying the action eg. posters, charts, maps, still images, etc. (3) Audio Visual Aids - is media that you can listen and see, e.g. television, computers etc.

The media is very contributing in helping students improve their mastery of English and greatly helps teachers in delivering teaching material to equalize students' perceptions. It has been proven by previous research, Lisa (2019) entitled The Effectiveness Of Flashcards On The Motivation To Increase English Vocabulary Among The Fourth Elementary School, there are 2 results obtained from this study, the first is a significant difference in learning motivation shown by fourth grade students before and after flashcard implementation (Instructional media) in teaching and learning activities. The second is a drastic difference in the mastery of fourth grade student's vocabulary before and after being taught with flashcards (Instructional Media). Other studies agree that instructional media has a positive impact to use when teaching English to young learners by Kusumawardhani \& Nurhayati (2019) entitled The Analysis of Teaching Writing to English Young Learners (EYL) through a Movie. The result of this study showed that film as one of the instructional media, has a very strong effect in helping young learners to improve their English skills.

As mentioned at the early that teaching young learners is not easy, especially in English lessons, even though English taught to elementary school students is local content, when teaching English in elementary school, teachers will meet students who have characteristics that different from adult students. That is some important factor in the use of media in teaching and learning activities of young learners, but in reality elementary school teachers rarely use media when teaching, and many teachers only use media provided by the school, sometimes not in accordance with the material, characteristics of children, and methods used.

This study aims to determine the use of media used in the activity of teaching and learning by teachers, problems found by teachers when using media, and strategies used to resolve problems when using media. By knowing how effective the media are in learning, it is hoped that this research will motivate teachers to maximize the use of media in the classroom in order to achieve effective and efficient learning goals

\section{METHOD}

This research method used in this study was qualitative research. qualitative research is research that seeks questions relating to social behavior and interpersonal interactions that drive certain 
social phenomena (Jameel, Shaheen, \& Majid, 2018). In line with Bodgan \& Biklen (1992) cited in Hidayah, Mulyati, \& Suprijadi (2019) who argue that qualitative research is one of the research procedures that will produce descriptive data in the written form and behavior of the people. Qualitative research has various types of designs, the type of qualitative design that is often used is Case study research, ethnography, grounded theory, narrative inquiry, Participation action, and phenomenology (Jameel et al., 2018). researchers used a case study design, case study is in-depth study of a phenomenon related with the specific context using various sources of data (Bhatta, 2018). This research is intended to find out the use of media in teaching English to young learners, started from what kind of instructional media that the teacher used for teaching english for young learner and the problems that faced in the use of instructional media then the solutions or strategies that teachers do to solved problems that arised when used instructional media

This study used 2 instruments in the process of collecting data, namely, observation and interview.

In observational data, researchers are only observers. Observation is intended to find out what media are used by the teacher during teaching activities, as well as the objectives in the selection of these media. Other instruments used in this study were interviews, interviews were used to dig deeper information about the teacher's perspective on the use of media in the classroom, interviews were conducted especially to find out the obstacles faced by the teacher when using media while teaching, and how the teacher's strategy in solving problems when used instructional media.

This research has been conducted in one elementary school in West Bandung district this research involved 25 grade 4 elementary school student and an english teacher.

The teacher aged 32 years, she has taught at the school for 8.5 years, starting the career as an English teacher, which means the teacher has also taught English for 8.5 years since she joined the school, she taught grades one through six, the teacher current status is still as an honorary teacher, teacher educational background is S1 English Language Education UIN, and S1 Universitas Terbuka (UT) Primary School Teacher Education. Because English at the school was included in local content.

\section{RESULTS AND DISCUSSION}

\section{Results}

\section{Types of instructional media used in teaching English to young learner}

The researcher conducted interviews with the teacher, and found that instructional media selection depends on the material and character of the students. Related to instructional media, teacher uses several media such as flashcards, puzzles, worksheets, course books, sometimes using projector and audio songs on the grounds that the school has many students, so according to teacher experience using these media is more effective for use in classroom situations consisting of many students for example video and flashcard are media that are often used in teaching and learning activities and the media the teacher has used at all grade levels, except songs (audio) is one of the high level media used in grade 6 only, all of these media have been for a long time he used it as a media, except for audio that was only 2 years old that teacher used because the school provided the equipment, the effectiveness of the media depended on students, but when viewed from student motivation, the media was very effectively used to attract the attention and focus of young learner, to apply projector more often used to watch 
videos, and audio is used to listen to songs and the teacher distributes work sheets containing missing lyrics then students listen with audio focus used to teach listening and writing, while flash cards are more often used for vocab. According to the characteristics of the students had intermediate and above characteristics and it made it easier for the teacher to use electronic media when teaching English, because some of them were already good at using gadgets, at least in the gadget there were some terms in English and students were faster in comprehension the material, especially vocab, although there are some students who are lacking in English, but more students who respond quickly, challenge in teaching young learners, according to teacher experience, because what is taught to young learners is basic English, the teacher does not find difficult obstacles in terms of the delivery of material, students always respond quickly and well, even in class, even the smallest such as classes 1 and 2 only 2 to 5 people who are sometimes difficult to digest the material.

To see the way teachers use instructional media, researchers come into the classroom, and observed the used of media by teachers during teaching activities. there are several media used by the teacher. the material learned at that time was a vocabulary of fruits, with an average of students aged 9-10 years (grade 4). The media are whiteboard, course book, and video. Before starting the lesson, the teacher prepared a instructional media.

At the beginning of the activity the teacher played a song about fruit vocabulary. The song is played 2x, then the teacher writes the lyrics of the song on the whiteboard so the song can be sung together. In the middle of the meeting the teacher used a whiteboard to write a vocabulary of fruits from English to Indonesian. The next activity the teacher also drew 3 pictures of fruit, and students were directed to describe the fruit, for example jack fruit that has thorny skin, large size, and stickiness. Other example, Banana, that has yellow skin, and smooth, has a sweet taste and long shape. After that, the teacher mentions a description of some fruits and the students guess what fruit the teacher means. Then, Students are instructed to do exercises, which are sourced from a coursebook, after making sure all students finish working on their assignments, The teacher gives a feedback. and discuss exercises that have been completed. At the end of the meeting, the teacher plays the song again, and sings with the students

\section{Problems faced by teacher in using instructional media}

There are some problems encountered when using media. (1) preparation, the teacher does not only use the media, but chooses media that is appropriate to the material, student characteristics, and to prepare for the use of instructional media, the teacher always takes too much lesson time. (2) electricity, not easy for teachers, to use projected media. It takes a long time to use projected media. The electricity and maintenance conditions are less likely to make media use become obstructed. In addition, an obstacle often encountered is that only a few classes have access to electricity. (3) access to using media provided by the school. the last difficulty experienced by teachers is access to use media that have been provided at school, when the teacher will use it, sometimes the cabinet where the media stored is still locked.

\section{Strategy undertaken to solve the problem by the teacher}

The solution to every obstacle in used instructional media in the classroom, the first solution is to maximize preparation in using media, before students come, the teacher has prepared it so that it does not take a lot of lesson time. the second solution, to maximize the use of projected media, the teacher should discuss this with the responsible party. The solution to the last problem is the difficulty of access to use media because the media storage cabinets are not free 
to be accessed by the teacher, therefore teachers have the initiative to create own instructional media, but teachers are faced with the problem of limited costs

\section{Discussion}

Based on the result The teacher in this study uses several media that help in the delivery of material that is tailored to the topic, material and methods and characteristics of students, one of the characteristics of students in this school is that they can use gadgets, so that it is easier to apply electronic media when teaching, media that are often used by The teacher is a flash card, a puzzle worksheet, a textbook, projector, and song.

The media used by the teacher when teaching fruit vocabulary material, are whiteboard, coursebook and song. The first media is white board, the purpose of using whiteboard is to write important and difficult words. There is a problem faced by the students, that it difficult to transfer the spoken to the written word. It is because English words are pronounced differently from Indonesian. In Indonesian, every single word is pronounced the same as its spelling (letter), while in English is not (Cahyati et al., 2019). whiteboard function for the teacher as as a media to draw something, and write some exercise

The second media is coursebook, it is used as a source of material and exercise. A textbook is the example of the teaching material that has been used for five decades as the manual instruction as well as a source of information in the teaching and learning activity (Karim, 2020).

The third media is song. the teacher played the song at the beginning of the meeting is to increased motivation, and stimulated the brain to start the lesson. Music is one of the most effective ways of influencing the emotional behavior of school children, because they perceive singing not as an educational process, but rather as a game or an activity for relaxation. Such activities not only completely change the atmosphere of the lesson, but also contribute to unconscious recognition of new words and (Vishnevskaia \& Zhou, 2019). According to the teacher the music makes the classroom atmosphere more attractive, especially if you add a little dance. The most important characteristics of young learner are their tendency to be active, some of them are more active than others (Cahyati et al., 2019). The teacher also played songs and sang with students, at the end of the lesson. Music And Song give students the opportunity to relax after mastering a complex topic without departing from the topic of the lesson and help students learn the usage of new words (Vishnevskaia \& Zhou, 2019).

According to the teacher, media is more suitable for use in large classes. The teacher feels very helped if teaching uses instructional media. Some of the benefits that teachers get from using instructional media included motivating, interesting attention, and student focus, Media in learning English plays a very important role, especially in learning English (Apsari et al., 2020)

The use of media teachers are hampered by school policies that hamper teachers' access to use learning media in schools, other than that another problem that teachers must face in preparing to use learning media, this occurs if teachers use projected media, because not all classes have access electricity. The teacher has the initiative to make instructional media on their own, but according to the teacher in making learning media the teacher is always faced with a limited budget. However according to Apsari et al. (2020) teachers should not be fixated on an expensive learning media, but instead they are expected to be able to utilize used goods that are still deserve to be used as an instructional media. 


\section{CONCLUSION}

The teacher in this school uses some of the media provided by the school to assist her in teaching namely flashcards, puzzles, worksheets and course books, sometimes using audio, the teacher believes that the above media is suitable for use with large numbers of students. Overall media in this school are used properly by teachers, teachers are skilled in using every learning media, but because of school policies that restrict teachers from accessing existing media, and the limited supporting media in using these media, the media is less maximizing teaching and learning activities. With the ability of teachers who are very skilled in using media, the use of media will be very effective to maximize teaching and learning activities, schools should pay more attention to the care of these media, and make it easier for teachers to access media and tools needed to use media, of course providing access to electricity in each room to make it easier for teachers to use projected media. If there are facilities and infrastructure that meet the teaching and learning process at the school will be more effective in using media to achieve learning objectives, because the existing learning media can all function properly as they should.

\section{ACKNOWLEDGMENTS}

Alhamdulillahi rabil 'alamin i reveal the highest gratitude to Allah Subhanahu Wa Ta'ala for blessing, opportunity, health, love and mercy to complete this scientific article, peace and blessing to our prophet Muhammad SAW, his Families, and the accompaniment of prayers, for his family, his companion and his followers

In completing this scientific article the researcher get lots of help and guidance and this occasion the researcher would express her appreciation to my supervisor, I am deeply indebted to Bapak Dasep Suprijadi, M.pd for warm support, inspiration, and thoughtful guidance and also i would like to thank everybody who was important to the successful realization of this article.

\section{REFERENCES}

Apsari, Y., Lisdawati, I., \& Mulyani, E. R. (2020). Alat Permainan Edukatif Sebagai Media Pembelajaran Bahasa Inggris. Abdimas Siliwangi, 03(01), 38-47. https://doi.org/DOI:http://dx.doi.org/10.22460/as.v3i1p\%25p.3385

Babiarz, M., \& Kraj, M. Z. (2019). The Importance and Chosen Techniques of Teaching Very Young Learners to Write in English. Edukacja-Technika-Informatyka, 10(1), 48-55. https://doi.org/10.15584/eti.2019.1.6

Bhatta, T. P. (2018). Case Study Research , Philosophical Position and Theory Building: A Methodological Discussion. Dhaulagiri Journal of Sociology and Anthropology, 12, 7279.

Cahyati, S. S., Parmawati, A., \& Atmawidjaja, N. S. (2019). Optimizing English Teaching And Learning Process To Young Learners (A Case Study In Cimahi). JEE (Journal of Educational Experts), 2(2), 107-114.

Hidayah, H., Mulyati, H. S., \& Suprijadi, D. (2019). Improving Students' Ability To Write Narrative. PROJECT (Professional Journal of English Education), 2(5), 634-639.

Jameel, B., Shaheen, S., \& Majid, U. (2018). Introduction to Qualitative Research for Novice Investigators. Undergraduate Research In Natural and Clinical Science and Technology (URNCST) Journal, 2(6), 1-6. https://doi.org/10.26685/urncst.57

Karim, I. (2020). An Overview of ELT Course Book (The Cultural Content In The Book " BAHASA INGGRIS "). Langua- Journal of Linguistics, Literature, and Language Education, 3(1), 1-8. 
Kusumawardhani, P., \& Nurhayati. (2019). The Analysis of Teaching Writing to English Young Learners (EYL) through a Movie: An ICT Perspective. Wanastra, 11(1), 25-36.

Lisa, H. (2019). The Effectiveness Of Flashcards On The Motivation To Increase English Vocabulary Among The Fourth Elementary School. JOALL (Journal of Applied Linguistics and Literature), 4(1), 43-53. https://doi.org/10.33369/joall.v4i1.6852

Muvango, M. W., Indoshi, F. C., \& Okwara, M. O. (2019). Use Of Media In Teaching English In Secondary Schools In Kakamega East Sub-County, Kenya. European Journal of Alternative Education Studies, 4(1), 75-81. https://doi.org/10.5281/zenodo.2591604

Soliu, S. A., \& Elisha, D. (2018). Instructional Media Provisions and Utilization for TeachingEffectiveness in Classrooms. KIU Journal of Social Sciences, 4(4), 163-170.

Vishnevskaia, M., \& Zhou, Z. (2019). The Impact of Using Music and Songs on Teaching EFL in China by Non-native English Teachers. Universal Journal of Educational Research, 7(8), 1808-1813. https://doi.org/10.13189/ujer.2019.070819 